\title{
Writing over time: An analysis of texts created by Year One students
}

Noella M. Mackenzie, Janet Scull, Terry Bowles

\author{
Noella M. Mackenzie \\ Charles Sturt University \\ nmackenzie@csu.edu.au \\ Janet Scull \\ Monash University \\ janet.scull@monash.edu \\ Terry Bowles \\ University of Melbourne \\ tbowles@unimelb.edu.au
}

\author{
Corresponding author \\ Janet Scull \\ Monash University \\ Email: janet.scull@monash.edu \\ Telephone +61399052841
}

\section{Writing over time: An analysis of texts created by Year One students}

\section{Introduction}

Learning to write is a complex physical and cognitive task, the rules of which are determined by social and cultural contexts (Bromley 2007). Myhill and Fisher (2010) describe writing as an effortful activity at all ages, while Kellogg (2008) draws parallels between learning to compose an effective extended text in its mature form, to learning how to play chess or a musical instrument. Each of these tasks, according to Kellogg (2008), demands motor skills, thinking, and memory, and learning them takes time, support, and practice. Despite the challenges writing presents, most young children successfully learn to compose and record messages with the help of more knowledgeable others.

Writing is central to children's literacy skills generally (Cutler and Graham 2008) and achievement in school overall (Fang and Wang 2011; Ritchey 2008). Those who are successful writers in the early years tend to continue to be good writers in the later years, while those who do not successfully learn to write in the early years of school often continue to struggle in the later years (Puranik and Lonigan 2014). For example, research by Abbott, Berninger and Fayol (2010) demonstrated stable individual differences in transcription skills (spelling and handwriting) necessary for the production of written language in the primary years, across early and later primary grades., skills With writing playing a significant role in young children's learning it is important to gain a clear understanding of the dimensions of writing critical to children's development. Specifically, knowledge of the areas of writing that contribute to the creation and production of increasingly more complex texts, and those areas that require focused intervention, are of particular relevance to teachers helping young students develop their writing craft (Clay 2001). While we acknowledge that there is no precise sequence of learning when it comes to writing (Askew 2009), our research identified and examined patterns that 
might scope possible learning journeys and assist teachers to monitor changes in students' writing during the early stages of their learning.

The elements of writing discussed here were derived from an analysis of texts collected from Year 1 writers (the second year of school in Australia). The multi-vector Writing Analysis Tool used in this study was based on the analysis of 210 texts randomly selected from a large data set of Year 1 students' texts collected as part of an earlier stage of the research (Mackenzie, Scull and Munsie 2013). The analysis resulted in the identification of six salient dimensions of writing: text structure, sentence structure, vocabulary, spelling, punctuation, and handwriting/legibility and six levels of performance. These dimensions, clearly evident as areas of competency and challenge for young writers in the texts surveyed, are also affirmed in the literature that considers factors important as young children learn to write, as discussed below.

\section{Learning to write}

Learning to write requires the ability to synchronize "skills such as handwriting, spelling, grammar, and punctuation" while at the same time keeping "track of such concerns as topic, organization, word choice, and audience needs" (Moats 2005/2006:12). Students' understanding of the dimensions of writing, both singularly and when integrated, develops as they move recursively across the different components of the process to compose and craft texts, and is central to effective assessment and teaching practice. To discuss these dimensions we have found it useful to use the terms authorial and secretarial, as described by Peters and Smith (1993). The authorial dimensions consider the composition of ideas and information communicated through the text, while the secretarial dimensions take account of the surface features and conventions of writing that allow a writer to accurately record written messages.

\section{Authorial dimensions of writing}

All writing is about communicating meaning and/or messages to oneself or others; translating thoughts into words (Abbott, Berninger and Fayol 2010). Hence, learning to generate a message and convey this with rhetorical style is the essence of the authorial dimensions (text structure, sentence structure and grammatical features and vocabulary) of writing. The first authorial element relates to the organisation of writing at the text structure level. Teachers consider learning to organize ideas and structure texts to be an important aspect of writing (McCarthey and Mkhize 2013). This element is well catered for in approaches to the teaching of writing in Australian schools, where writing pedagogy has been strongly influenced by the genre movement with its emphasis on the explicit teaching of forms, organizational structures and linguistic features of different types of writing (Christie 2005; Martin, Christie and Rothery 1987). Frow (2005:10) states, that genre "is central to human meaning-making and to the social struggle over meanings". Moreover, understanding how the communicative purpose of a text shapes the underlying structure and language features is an essential component of instructional programs in the early years of schooling and beyond (Gibbons 2002; Cloonan, Scull and Turpin 1998; Wing Jan 2009). 
The second authorial element relates to the overall organization of a text is the ability to express ideas at the sentence level with clarity, using appropriate word and phrase order consistent with standard usage patterns. This requires young writers to develop control over written discourse patterns, showing awareness of correct sentence grammar and use of a variety of sentences types (from simple to compound, to complex structures). Similarly, students need to know how sentences are combined to ensure the flow of ideas and to build a coherent, cohesive text (Derewianka 2011). Teaching that supports students to move beyond tacit understandings of sentence structure is critical, as they make conscious choices about how to best express ideas and convey understandings (Locke 2010; Quinn 2004).

Vocabulary, the third authorial element discussed here, has been linked to success with reading specifically and school more generally (see for example, Beck, McKeown \& Kucan, 2013; Snow, Porche, Tabors and Harris 2007; Storch and Whitehurst 2002; Wasik 2010). Further, a need for a strong command over vocabulary is reflected in curriculum frameworks that stress the importance of students developing and extending their vocabulary and ability to make appropriate word choices when creating texts (ACARA 2013b). We argue that a wide and varied vocabulary is also important as students construct texts with nuanced meanings. Being able to make lexical choices appropriate to an audience and purpose allows students to develop their ideas and add detail and interest to their texts. While text structure, sentence structure and vocabulary work together to assist the writer to compose or author their writing, young writers also need to be skilled in the secretarial dimensions of text creation.

\section{Secretarial dimensions of writing}

Learning to control the secretarial dimensions (spelling, punctuation and handwriting) of writing requires an understanding of the surface features or conventions of print and fits with the notion of transcription; translating language into text (Abbott, Berninger and Fayol 2010). Control over these secretarial skills and strategies allows for complexity of meaning and frees attention from the challenges of recording thoughts, so that messages of the students' choice can be recorded and read by others (Berninger and Swanson 1994).

Writing also requires "word-level language using written symbols in conventional sequences (orthography) that represent speech sounds (phonology) and word parts that signal meaning and grammar (morphology)" (Garcia, Abbott and Berninger 2010:63). Therefore, to write with efficiency and automaticity requires the development and accurate application of culturally determined spelling systems or rules (Wulff, Kirk and Gillon 2008). Considerable empirical research investigating students' control over spelling patterns supports a staged, sequenced view of learning knowledge of the alphabet and letter sounds, followed by understanding of letter patterns and sequences, and then awareness of the meaning relationships between English words (Ganske 2000; Gentry 1982). However, Young (2008) cautions that the progress through the stages described is not always tidy, concluding that stage theory does "not capture all knowledge and strategies which students are found to use when engaged in spelling-related activities" (Young 2008:137) as students often demonstrate non-stage related 
processes. Evidence for non-linear models has also been provided by Garcia et al. (2010) and Perfetti and Hart (2002). Importantly, the messages students create are not limited by their ability to spell, and that students have a range of skills and strategies they can employ to spell known and new words.

Just as learning to spell involves developing control over systems and conventions of language so does the use of punctuation. All "writing systems use a variety of forms of representation including special signs for names, namely capitalization, signs for sentences, namely capitals and periods [full stops], and the like" (Olson 2009:9). These symbols are used to 'package ideas' into units of meaning. A conscious and deliberate use of punctuation allows a writer to express their ideas with clarity and precision, leaving less room for misunderstanding.

Finally, fluent, legible handwriting allows messages to be recorded effortlessly and retrieved quickly. Ease of handwriting appears to support the creation of more complex meanings, with handwriting being the skill that 'places the earliest constraints on writing development' (Graham (2009/2010:20). According to Schlagal (2007), Graham (2009/2010), Medwell and Wray (2008) and Torrance and Galbraith (2006) there is a significant relationship between compositional skill and handwriting fluency particularly, but not exclusively, for young writers. Further, efficient transcription skills may reduce working-memory demands and ensure capacity is available for higher-level message generation processes. Current research supports the importance of speed and fluency of handwriting to a child's ability to produce high-quality written texts (Berninger and Swanson 1994; Boscolo 2008; McCutchen, Teske and Bankston 2008; Medwell and Wray 2008).

\section{Writing, SES, Gender and English Language Learning}

The early literacy research literature also points to socio-economic status, gender and language backgrounds as impacting on students' learning trajectories.

The connections between students' socio economic background and their learning outcomes in schools have been well documented (Zbar, Kimber \& Marshall 2009). Differentiated results according to socio economic status (SES) have long been reported; notable is the work of Bernstein (1970) who described the underachievement of the working class and how class impacts on students' ability to profit from educational experience. The Gonski review, established to develop a funding system for Australian schooling effective in promoting excellent outcomes for all Australian students, noted the "unacceptable link between low levels of achievement and educational disadvantage, particularly among students from low socioeconomic and Indigenous backgrounds" (Gonski, et al. 2011: xiii). Teese and Lamb (2009) further highlight the inequity of students' outcomes as measured by social class and location. They state that "children exposed to social differences in family upbringing are also exposed to differences in the social mix and culture of the schools they are enrolled in" (Teese \& Lamb 2009:3). Large-scale international and national literacy test results provide further evidence of the link between SES and student outcomes. The 2009 Programme for International Student Assessment 
(PISA), reported on reading literacy performance and socio economic background and found SES a significant factor in achievement (OECD 2010). Specific to attainment in writing, the Australian National Assessment Program, Literacy and Numeracy (NAPLAN) reports students' writing outcomes using parent occupation to disaggregate the performance results. The results show that students from higher income families consistently achieve better outcomes at Year 3 and Year 5 (ACARA 2012; ACARA 2013a; ACARA 2014). An intention of this study was to ascertain whether performance trajectories related to SES were evident at Year 1 and if this was consistent across the different dimensions of writing. In this study, participants were grouped using each school's Index of Community Socio-educational Advantage (ICSEA) score as an indicator of SES. The possibility of a relationship between gender and writing achievement was also of interest to the researchers.

The literacy underachievement of boys has been a focus of intense concern in Australia for at least two decades (Comber 2004, Hodgetts 2008), similarly in the United Kingdom (Jones and Myhill 2004; Lingard, Martino and Mills 2009), the United States of America (Below, Skinner, Fearrington and Sorrell 2010; Whitmire 2010), Denmark, Germany and Japan (Yates 1997). In Australia, the NAPLAN results for students in Year 3 consistently demonstrate that girls outperform boys in the literacy items tested (ACARA 2013a). Skelton and Francis (2011) also reported a gender gap in the 2010 National Assessment of Educational Progress (NAEP) scores and highlighted a particular gap in the writing proficiency of girls and boys. Reasons provided for these outcomes are varied. While Whitehead (2006) claims that girls start school better prepared to meet the demands of school than boys, Lindsay and Muijs (2006) suggest that any underachievement experienced by boys must be examined in conjunction with socio-economic circumstances and ethnicity. DiPrete and Jennings (2012) argue that the social and behavioural skill differences between girls and boys help to explain academic differences right across the primary years. Below and colleagues (2010) referring to a study conducted by Leinhardt, Seewald, and Eagle in 1979, suggest that teacher expectations and instructional contact vary between girls and boys, with boys receiving more mathematics instruction and girls more reading instruction. However, Mills, Martino and Lingard (2007) following Connolly (2004) challenge the notion of boys as the 'new disadvantaged', pointing out that not all boys underachieve in literacy (Lingard, Martino and Mills 2009). The research presented here indicates the need for a more nuanced approach that considers which boys are at risk in the literacy classroom (Martino 2003). When discussing our findings we pay particular attention to the growth of the boys in our study.

Written discourse often poses challenges for young learners as they learn to compose and construct messages, controlling the endophoric references that make it internally coherent and understandable apart from the context in which it was composed (Christie 2005). Many students when first learning to write use oral language forms, shifting to written language as they mature and become familiar with the language we write as distinct from the language we speak (Raban 1999; 2014). However, for students learning English as an Additional Language (EAL), the learning required may be extensive, as they become aware of the differences between speech and writing, the organizational structure of different text types and the grammatical patterns of English (Gibbons 2002). Cummins indicated that while 
conversational language is acquired quickly, "academic language proficiency, including knowledge of less frequent vocabulary as well as the ability to produce increasingly complex written language may take at least five years" (2001:73).

\section{The Present Study}

Cognizant of the dimensions of writing that impact on proficiency, we measured students' writing at a critical stage of learning; during the second year of school. Our intention was to discover what dimensions of writing these students controlled, what changes occurred across collection times 1 and 2, and to identify areas that might require attention. We were also interested in identifying and examining differences across cohort groups; specifically Socio-educational advantage groups, EAL learners, and gender. Further we were interested in identifying patterns or relationships evident across the authorial and secretarial dimensions of writing discussed earlier.

\section{Participants}

This paper reports the analysis of 500 writing samples, collected from 250 students at two time points. The sample set is drawn from our larger data base of writing texts collected from 1799 Year 1 students from 75 schools in Victoria or New South Wales, Australia. Schools, via teacher networks, were invited to participate in the study to provide opportunity for a representative sample accounting for socio-educational advantage, language background and location (including metropolitan, regional and rural schools). Of the 250 participating students 132 were females and 118 males. A small sample of EAL student were included in this analysis $(n=40)$.

\section{Procedure}

Writing samples were collected, with the assistance of classroom teachers in July/August and November/December, which correspond to the midpoint and the end of the school year. The data collection required that the prompt to stimulate writing be broad and not tied to particular approaches, cultural contexts or curriculum priorities. We also aimed to minimize teacher impact. Nonetheless we appreciate that the texts students produced are likely to be influenced by those texts modelled, shared, discussed and valued in their classrooms. Teachers were asked to introduce the task in the following way: "Today you can choose to write about anything you like". The researchers made the decision to give an open-ended prompt so that all children would have the scope to respond in ways they felt comfortable. An analysis of the topics and text types will be the focus of a future paper. Students were to be given 20 minutes to complete their written texts and teachers collected and de-identified the samples. The researchers accept that some teachers may have allowed their students a little more or less time, despite the researchers' instructions, and that this may help to explain the variation in length of samples. Demographic details of gender and language background were recorded by the teachers alongside a school, class and student numeric code for matching purposes, before teachers forwarded the texts to the research team for analysis. Students completed the same task four to five months apart. The study was performed with approval from the University's Human Research Ethics Committee and relevant school systems. Parents approved their child's participation and students' assent was gained. 
The analysis tool was developed in an earlier stage of the research project through the identification of observable categories of writing evident in an initial sample set of texts. These categories were modified to include six discrete areas or dimensions of writing, using a process of expansion and reduction. The range of complexity within each dimension was scoped and descriptors developed and tested by the researchers until consensus across the four research team members was achieved (Mackenzie, Scull and Munsie 2013). Coding of the texts reported in this paper was conducted independently by three members of the research team, with each text cross checked to ensure consistency of interpretation and use of the descriptors. A copy of the writing analysis tool is attached (Appendix 1).

A series of within-between ANOVAs and weighted cross tabulations were performed to assess differences between groups (frequencies, Time 1/Time 2, SES, gender and EAL status). ANOVA is a standard technique for establishing the difference between groups by statistically separating the variance accounted by each of the levels of the independent variables (in these analyses, Time 1/Time 2, SES, gender and EAL status) on specified continuous variables, in these analyses the dimensions of writing (Cohen 1988; Field 2009). SES was measured using the Index of Community Socio-educational Advantage (ICSEA) -a standard method of generating categories consistent with previous research (Anderson \& Curtin 2014). Each Australian school is given a weighted value based on the level of advantage/disadvantage, remoteness, and the presence of groups with specific needs. The standardized values range from approximately 500 to 1300 with a median of 1000 and a standard deviation of 100 (ACARA 2013c). Correspondingly, approximately two-thirds of schools in Australia will have an ICSEA value between 900 and 1,100. As relatively equivalent numbers of schools from each SES group were invited to participate a full range SES strata was expected. A four group categorization was designed with a low ICSEA group less than 899; a lower-middle, 900-999; an upper middle group, 1000-1099; and a high group, greater than 1100. As only four schools were present in the low ICSEA group, these schools were combined with the lower-middle ICSEA group resulting in a three group subdivision - a Low Average ICSEA group (LAI: ICSEA score < 999), a High Average ICSEA group (HAI: ICSEA range 1000-1099) and an Above Average ICSEA group (AAI: ICSEA score > 1100).

\section{Results}

\section{Demonstrated levels of writing achievement}

The primary focus of the research reported here was to examine the general level of competence achieved by Year 1 students across the dimensions defined by the writing analysis tool, and to explore changes that occurred across the two data collection times. The distribution of scores across the six dimensions indicates the range in competence apparent at both data collection points (see Appendix 1).

There were significant mean differences in the six dimensions of writing between Time 1 and Time 2, indicating improvement in each aspect of writing measured over the data collection period (see Table 1). However, the magnitude of growth for three of the dimensions (sentence structure, spelling, and 
handwriting) were considered small while three dimensions (text structure, vocabulary and punctuation) demonstrated growth in the medium range of magnitude (Cohen 1988).

Table 1: Means, Standard Deviations and Significance Statistics for Dimensions of Writing Process at Time 1 and 2.

\begin{tabular}{|c|c|c|c|c|c|c|c|c|}
\hline & \multicolumn{2}{|c|}{$\mathrm{T} 1(n=250)$} & \multicolumn{2}{|c|}{$\mathrm{T} 2(n=250)$} & \multirow[b]{2}{*}{$F$} & \multirow[b]{2}{*}{$p$} & \multirow[b]{2}{*}{$\eta^{2}$} & \multirow[b]{2}{*}{$D$} \\
\hline & Mean & SD & Mean & SD & & & & \\
\hline Text Structure & 4.12 & 1.03 & 4.45 & .86 & 33.18 & .001 & .12 & .35 \\
\hline Sentence Str & 3.61 & .74 & 3.70 & .68 & 4.07 & .045 & .02 & .12 \\
\hline Vocabulary & 3.59 & .78 & 4.03 & .66 & 90.89 & .001 & .27 & .29 \\
\hline Spelling & 3.30 & .81 & 3.50 & .84 & 12.18 & .001 & .05 & .24 \\
\hline Punctuation & 2.47 & .90 & 2.85 & .97 & 28.57 & .001 & .11 & .41 \\
\hline Handwriting & 3.37 & .94 & 3.64 & 1.00 & 19.59 & .001 & .08 & .28 \\
\hline
\end{tabular}

Disaggregating this data Table 2 shows how the frequency of students at each performance level changed over the two time periods. Frequency scores for each of the six levels of achievement are noted for Time 1 to Time 2 .

Table 2: Frequency Table for Dimensions Writing at Time 1 and Time 2

\begin{tabular}{|c|c|c|c|c|c|c|}
\hline \multirow[t]{2}{*}{ Dimensions of writing } & \multicolumn{6}{|c|}{ Performance Level } \\
\hline & 1 & 2 & 3 & 4 & 5 & 6 \\
\hline Text Structure T1 & 5 & 11 & 48 & 79 & $\underline{100}$ & 7 \\
\hline Text Structure T2 & 1 & 5 & 33 & 59 & $\underline{145}$ & 7 \\
\hline Sent Structure T1 & 4 & 9 & 86 & $\underline{133}$ & 18 & 0 \\
\hline Sent Structure T2 & 0 & 7 & 82 & $\underline{141}$ & 18 & 2 \\
\hline Vocabulary T1 & 4 & 9 & 96 & $\underline{119}$ & 21 & 1 \\
\hline Vocabulary T2 & 0 & 6 & 31 & $\underline{163}$ & 49 & 1 \\
\hline Spelling T1 & 4 & 20 & $\underline{143}$ & 68 & 11 & 4 \\
\hline Spelling T2 & 2 & 19 & $\underline{112}$ & 88 & 28 & 1 \\
\hline Punctuation T1 & 15 & 150 & 44 & 34 & 7 & 0 \\
\hline Punctuation T2 & 8 & $\underline{107}$ & 59 & 67 & 9 & 0 \\
\hline HandwritingT1 & 3 & 33 & $\underline{116}$ & 71 & 21 & 6 \\
\hline Handwriting T2 & 3 & 24 & 83 & 104 & 23 & 13 \\
\hline
\end{tabular}

In terms of text structure at Time 1 , the students were mainly spread across level $4(n=79)$, producing samples with four or more connected, clearly sequenced ideas, and Level $5(n=100)$, the mode (most frequent or common score achieved), with texts that demonstrated the structure of specific text types. At Time 2, an increased number of students were demonstrating control over the linguistic structure of text types level 5, $\mathrm{n}=145)$. At this level, samples were often recount texts, including an orientation and temporal sequence of events (see Figure 1). Other texts produced were narratives, with students demonstrating a developing understanding of introductions, complications and resolutions in their texts.

Figure 1: Text Structure - developing control over the structure and features of text types (recount) 


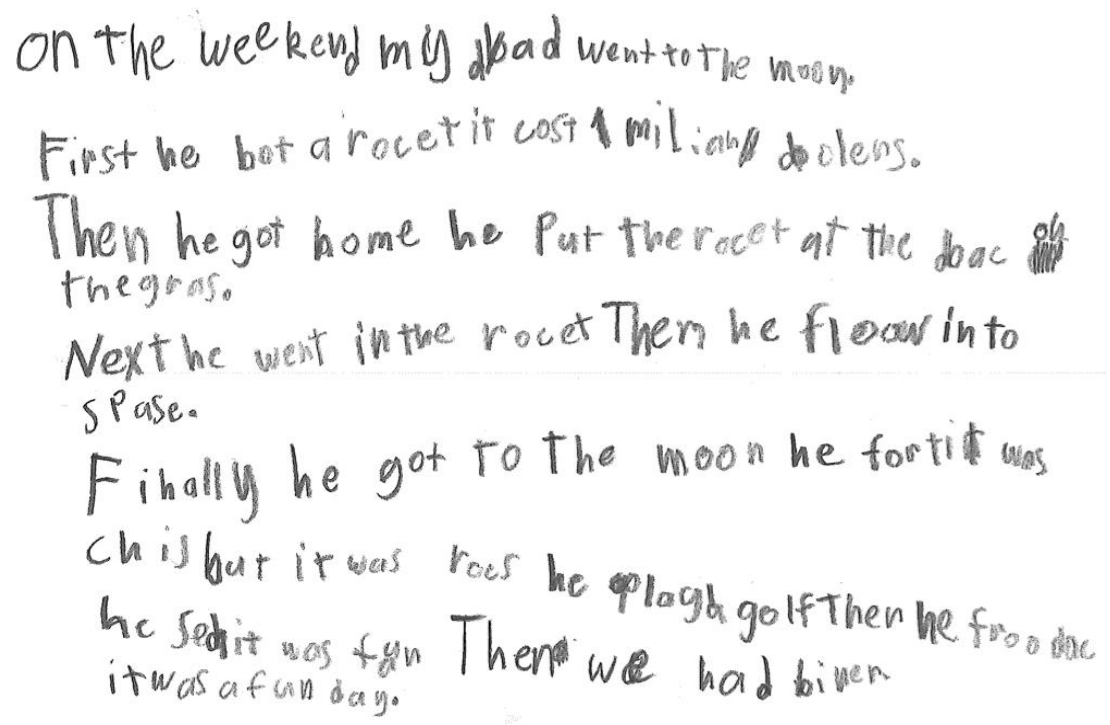

(on the weekend my dad went to the moon. First he bot a rocet it cost 1 milian dolers. Then he got home he put the rocet at the bac on the gras. Next he went in the ricket Then he floaw in to spase.

Finally he got to the moon he fort it was chis but it was rocs he playd golf then he froo dac he sed it was fun Then we had biner it was a fun day.)

Over the data collection period, the dimension that showed the least change in both mean scores and distribution was sentence structure. The mean score increased from 3.61 to 3.70 , with students generally spread across levels 3 and 4. There was consistency also in the number of students' texts assessed at these levels. At Time 1, 86 texts were assessed at level 3 and at Time 2 a further 82 texts were assessed at level 3. This indicated students were using simple clauses, with nouns, verbs and adverbs, which may be linked by “and". At Time 1, there were 133 texts assessed at Level 4 (the mode) with an increase to 142 texts at Time 2. At level 4, texts included both simple and compound sentences with appropriate conjunctions (e.g. and, but, then) and the use of adverbial phrases to indicate when, where, how or with whom (see Figure 2).

Figure 2: Sentence Structure - use of simple and compound sentences and adverbial phrases 


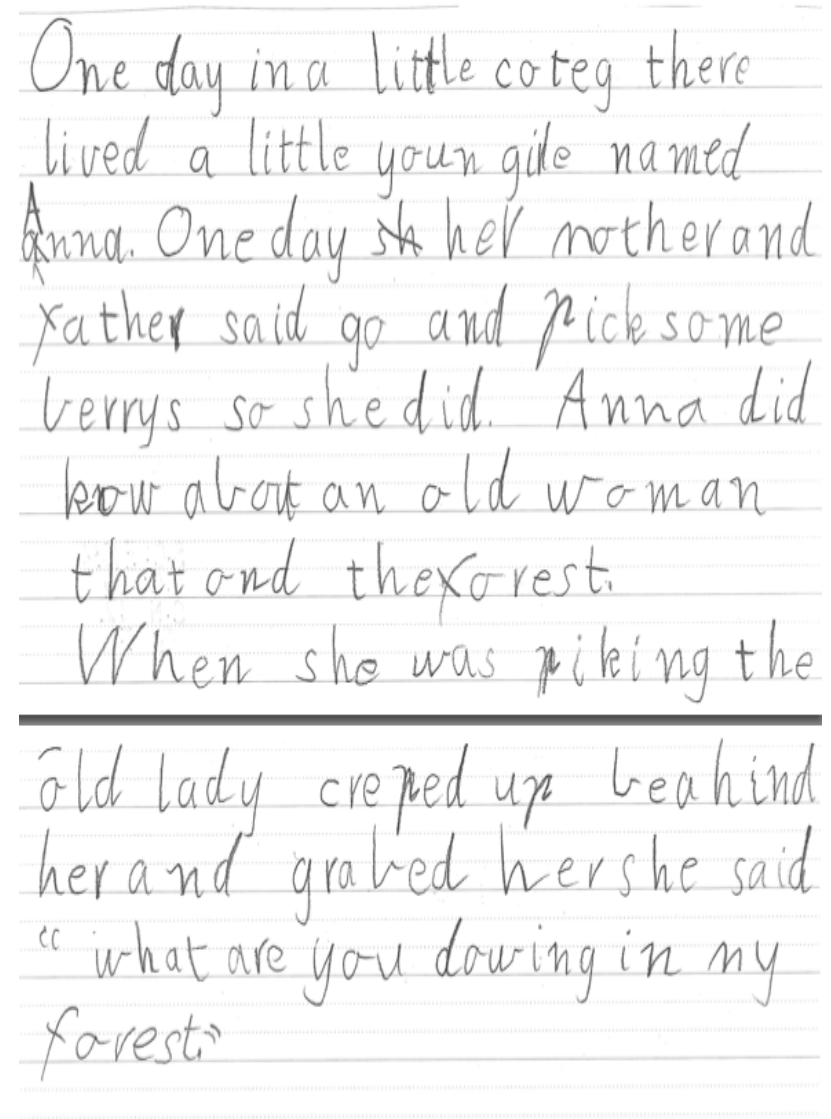

Changes to students' vocabulary used in the texts assessed indicated an increase in their written vocabulary, with a clear shift from everyday words to more topic specific language (see Figure 3). There was an increase in the use of topic specific words over the data collection period with totals for level 4 at Time $1(n=119)$ and at Time $2(n=163)$, the mode. Further, at Time 2, 25\% of students $(n=49)$ produced texts to level 5 , with a variety of lexical choices and texts that included descriptive or emotive language.

Figure 3: Vocabulary - from everyday words (Text a) to topic specific word choices (Text b)

Text a

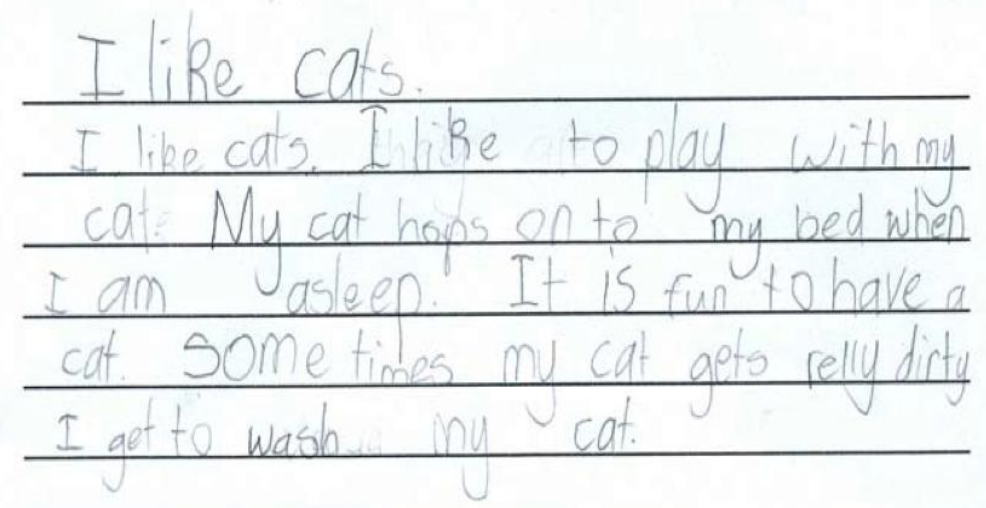


Text b

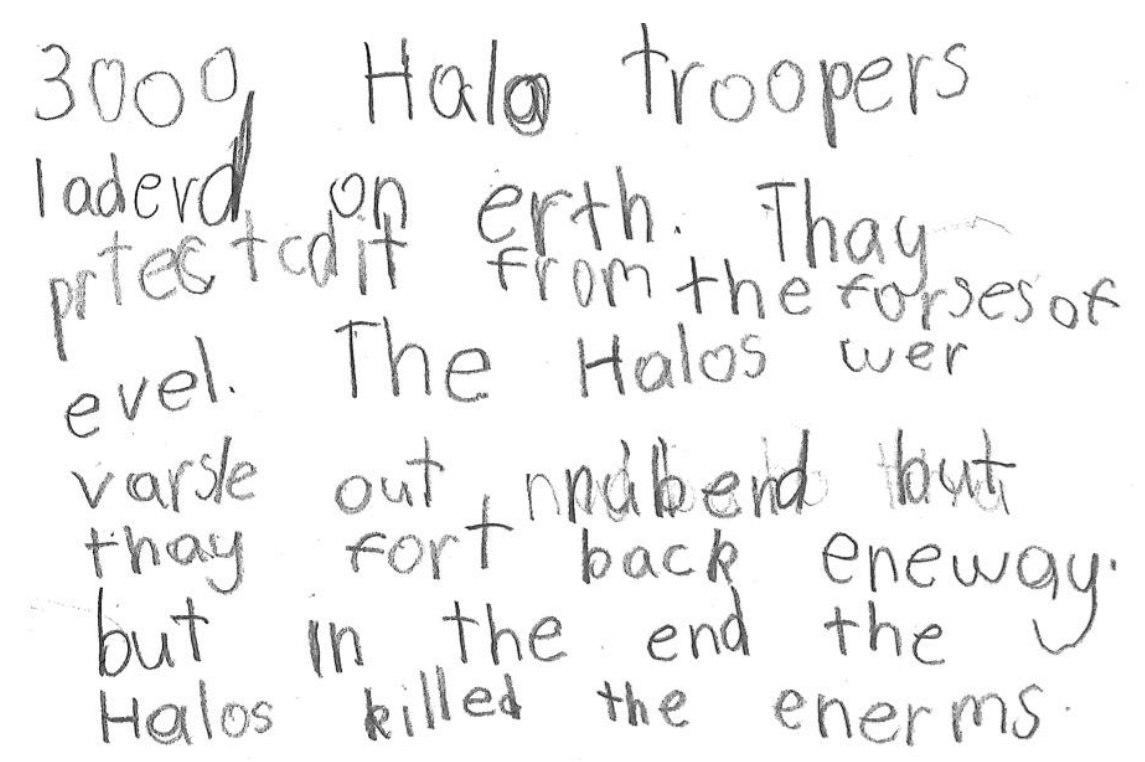

Between Time 1 and Time 2, changes were evident in students' control over spelling, with a shift from plausible spelling attempts with most sounds in words represented, to an increased use of orthographic patterns and correct letter sequence to represent sounds. At time 1, over half the texts analysed $(n=143)$ showed evidence of students as 'phonetic spellers', making plausible attempts to spell unknown words, with most sounds represented (see Figure 4). By Time 2, over a third of the texts assessed $(n=88)$ indicated students had moved to a greater use of correct orthographic patterns for common English letter sequences.

Figure 4: Spelling - Phonetic spelling, evidence of plausible spelling attempts

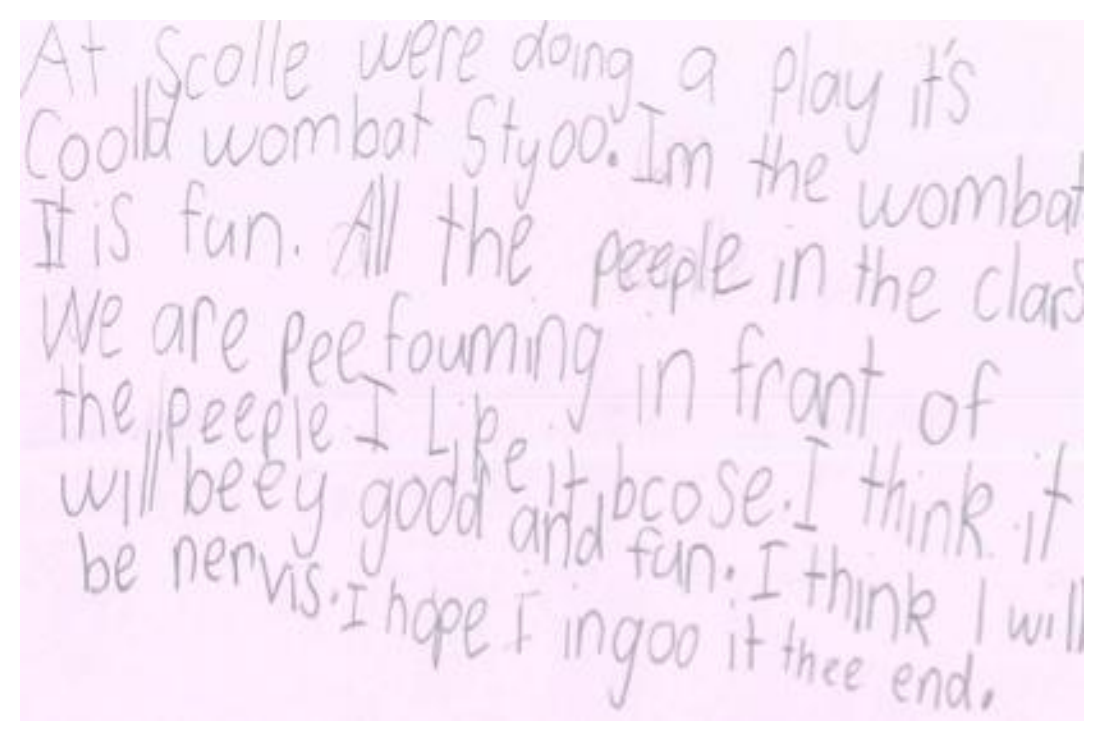


With regard to punctuation, the texts analysed indicated that the majority of students in the sample were familiar with full stops and capital letters. However, these were not always used consistently. At Time 1, most students $(n=150)$ showed some use of capital letters and full stops, generally at the end and beginning of their texts. By Time 2 this number had reduced $(n=107)$, with more students $(n=59)$ able to demonstrate a correct use of full stops and capital letters, while other students $(n=67)$ were experimenting with a range of punctuation forms including quotation, question and exclamation marks. Figure 5 show the range of attainment at these two time points.

Figure 5: From inconsistent use of capital letters and full stops (Text a) to experimenting with a range of punctuation forms (Text b)

Text a

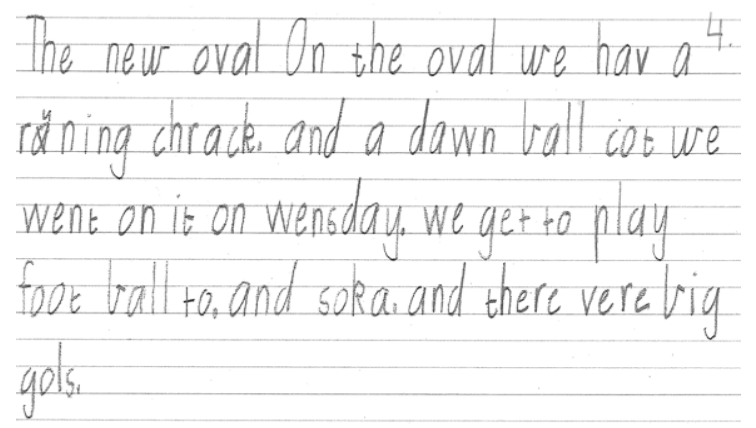

Text b 


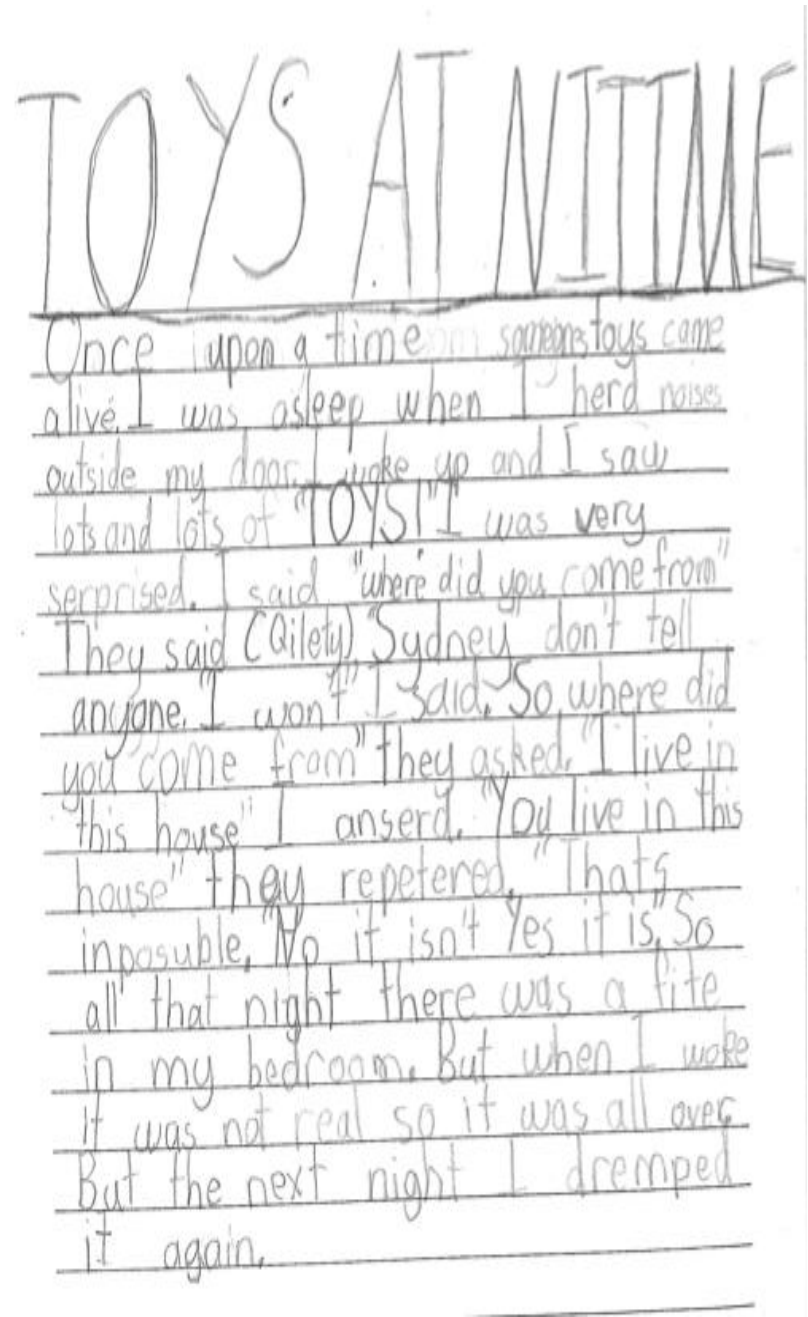

Handwriting development, from the texts analysed, showed students' level of control ranged from levels 3 to Level 4. At Time 1, 116 students demonstrated mostly correct letter formation, with texts generally easy to read. By Time 2, a modal shift had occurred from level 3 and 4 with many students $(\mathrm{n}=104)$ forming letters correctly and demonstrating good control over the position of letters and spacing of letters and words (see Figure 6).

Figure 6: Handwriting - Correct letter formation, with good control over positioning and spacing of letters and words

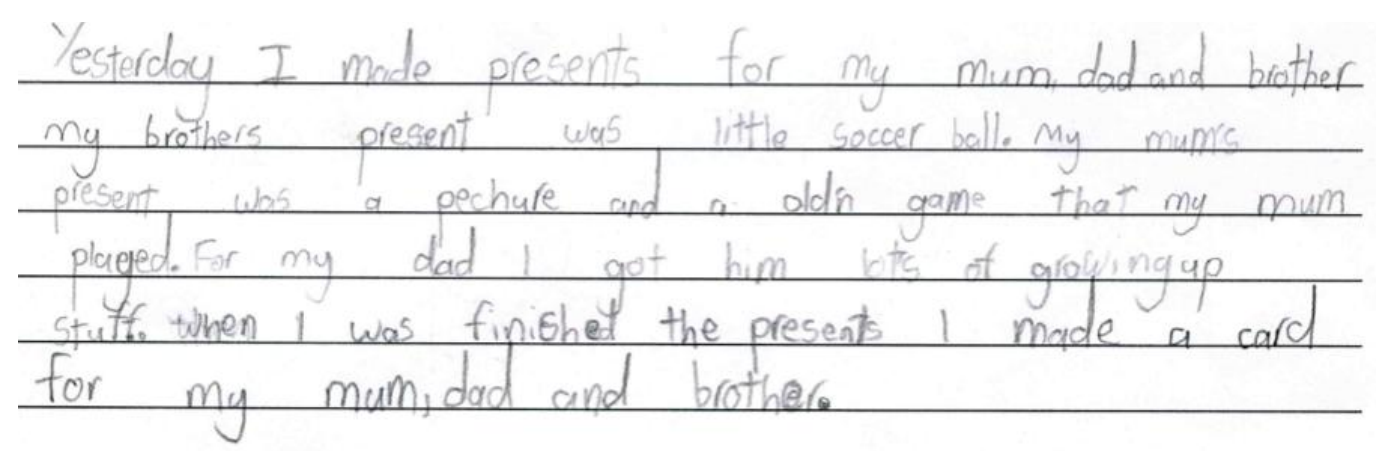




\section{SES and writing}

In the study, participants were grouped using school ICSEA scores as a proxy for SES. The ANOVA involving ICSEA groupings showed different attainment levels across each of the three ICSEA groups at the two data collection points, with relatively consistent gains from Time 1 to Time 2 for all groups. There were no interactions involving time of testing and ICSEA groupings (see Table 3).

At Time 1, the Low Average ICSEA (LAI) group were significantly below the High Average ICSEA (HAI) and Above Average ICSEA (AAI) groups on every dimension. The LAI group's scores for each dimension were between levels 3 and 2. At Time 2, the LAI group's scores had increased, with the score for sentence structure equal to the HAI group.

The HAI group maintained a trajectory of growth on each dimension with scores generally above the LAI group and below the AAI group. The exception to this pattern is in the average score for sentence structure (average 3.63 at Time 1 and 3.59 at Time 2). While there was a lower average score at Time 2 , the scores were not significantly different.

The AAI group comparison scores showed some variation between the authorial and secretarial aspects of writing. The average AAI scores for text structure and sentence structure were significantly higher than the LAI and HAI group at Time 1 and 2. The AAI group's score for vocabulary at Time 1 was similar to the HAI group but had increased at Time 2. The AAI group's scores for the secretarial aspects of writing at Times 1 and 2 were similar to, or below, the HAI group.

Table 3; Means, Standard Deviations and Significance Statistics for Dimensions of Writing Process by ICSEA groupings at Time 1 and 2.

\begin{tabular}{|c|c|c|c|c|c|c|c|c|c|}
\hline \multirow[b]{2}{*}{ Time 1} & \multicolumn{2}{|c|}{$\mathrm{LAI}^{1,2}(\mathrm{n}=78)$} & \multicolumn{2}{|c|}{ HAI $(n=92)$} & \multicolumn{2}{|c|}{$\operatorname{AAI}(n=80)$} & \multirow[b]{2}{*}{$F$} & \multirow[b]{2}{*}{$p$} & \multirow[b]{2}{*}{$\eta$} \\
\hline & Mean & SD & Mean & SD & Mean & SD & & & \\
\hline \multicolumn{10}{|l|}{ Time 1} \\
\hline Text Structure & $3.62^{\mathrm{ab}}$ & 1.07 & $4.26^{\mathrm{a}}$ & .88 & $4.44^{b}$ & .95 & 15.84 & .000 & .11 \\
\hline Sentence Str & $3.40^{\mathrm{ab}}$ & .80 & $3.63^{\mathrm{a}}$ & .71 & $3.79^{b}$ & .69 & 5.71 & .004 & .04 \\
\hline Vocabulary & $3.22^{\mathrm{ab}}$ & .81 & $3.78^{\mathrm{ab}}$ & .66 & $3.72^{\mathrm{b}}$ & .75 & 14.34 & .000 & .11 \\
\hline Spelling & $3.09^{\mathrm{a}}$ & .76 & 3.32 & .76 & $3.48^{\mathrm{a}}$ & .87 & 4.68 & .010 & .04 \\
\hline Punctuation & $2.26^{\mathrm{a}}$ & .75 & 2.61 & .94 & $2.52^{\mathrm{a}}$ & .97 & 3.50 & .032 & .03 \\
\hline Handwriting & $3.15^{\mathrm{a}}$ & .90 & $3.50^{\mathrm{a}}$ & .98 & 3.43 & .91 & 3.13 & .045 & .03 \\
\hline \multicolumn{10}{|l|}{ Time 2} \\
\hline Text Structure & $4.01^{\mathrm{ab}}$ & .99 & $4.63^{\mathrm{a}}$ & .69 & $4.68^{b}$ & .74 & 16.74 & .000 & .12 \\
\hline Sentence Str & $3.59^{\mathrm{a}}$ & .73 & $3.59^{\mathrm{b}}$ & .58 & $3.95^{\mathrm{ab}}$ & .67 & 8.22 & .000 & .06 \\
\hline Vocabulary & $3.78^{\mathrm{abc}}$ & .64 & $4.04^{\mathrm{abc}}$ & .64 & $4.27^{\mathrm{abc}}$ & .62 & 12.08 & .000 & .09 \\
\hline Spelling & $3.28^{\mathrm{ab}}$ & .87 & $3.59^{\mathrm{a}}$ & .73 & $3.60^{\mathrm{b}}$ & .89 & 3.79 & .024 & .03 \\
\hline Punctuation & $2.46^{\mathrm{ab}}$ & .82 & $3.13^{\mathrm{a}}$ & .98 & $2.90^{\mathrm{b}}$ & 1.00 & 10.93 & .000 & .08 \\
\hline Handwriting & $3.44^{\mathrm{a}}$ & .95 & $3.82^{\mathrm{b}}$ & 1.03 & 3.63 & .99 & 3.11 & .046 & .03 \\
\hline
\end{tabular}

\section{Writing and gender}


Our analyses showed that females consistently scored higher than males on all six aspects measured at Time 1 and Time 2 (see Figure 7) and while there were statistically significant gender effects, the magnitude of the difference was small (see Appendix 2 for Means, Standard Deviations and Significance Statistics for Dimensions of Language by Time and Gender at Time 1 and 2). It is worth noting however, that the mean score for females was also achieved by many males. While females were assessed as attaining higher levels of writing generally, the scores attained for vocabulary and spelling were not significantly different for gender at Time 1 and sentence structure was not significant at Time 2.

Similar patterns of growth were also evident for each gender, with both males and females showing a consistent rate of change over the data collection period. There were also no interactions evident, as the differences between genders were not related to changes between Time 1 and Time 2 . Correspondingly, the differences between times were not associated with gender differences.

Figure 7: Gender Differences for the Dimensions Writing at Time 1 and Time 2

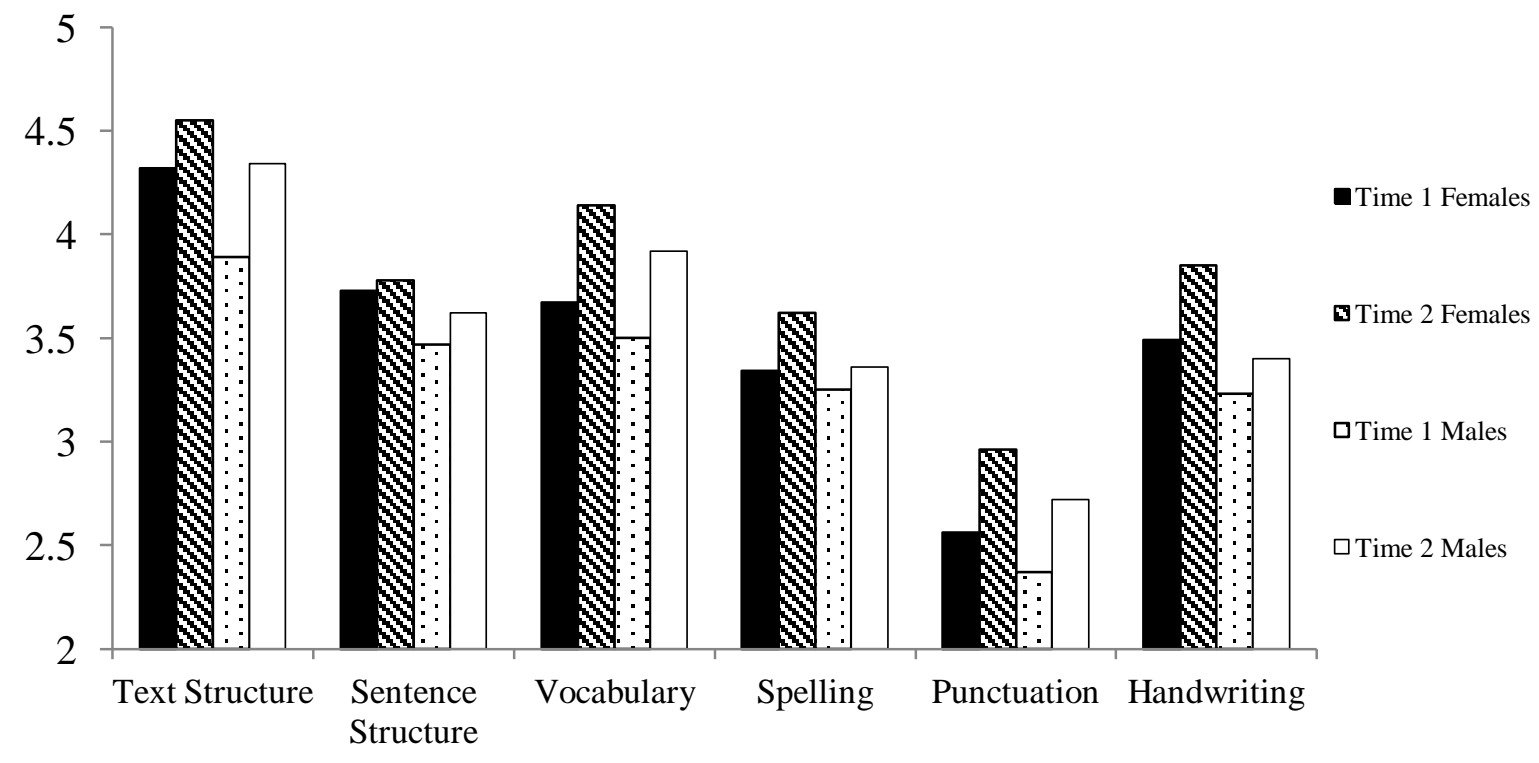

\section{EAL students' writing development}

We analysed samples from 250 students and 40 of these students were learning English as an additional language (EAL) (see Table 4). While this is a small subsample, the data proved interesting. The results show that EAL students at Times 1 and 2 were demonstrating a control over the six writing dimensions that was, on average, lower than the Non EAL group. However, the gains made over time for the EAL students were greater in 4 of the 6 dimensions than those made by those students who spoke English as their first language. See Appendix 3 for Means, Standard Deviations and Significance Statistics for dimensions of Language by EAL at Time 1 and 2.

Table 4: Means, Time 1 and Time 2 and gains for non EAL and EAL students 


\begin{tabular}{lcccccccc}
\hline & \multicolumn{3}{c}{ Non EAL $(n=210)$} & \multicolumn{3}{c}{ EAL $(n=40)$} \\
& Mean & Mean & Gain & \% Gain & Mean & Mean & Gain & \% Gain \\
& T1 & T2 & on T1 & on T1 & T1 & T2 & on T1 & on T1 \\
\hline Text Structure & 4.23 & 4.49 & .26 & 6.1 & 3.53 & 4.25 & .72 & 20.4 \\
Sentence Structure & 3.67 & 3.72 & .05 & 1.3 & 3.28 & 3.60 & .32 & 9.8 \\
Vocabulary & 3.65 & 4.08 & .43 & 11.7 & 3.28 & 3.78 & .50 & 13.1 \\
Spelling & 3.29 & 3.50 & .21 & 6.4 & 3.33 & 3.45 & .12 & 3.6 \\
Punctuation & 2.50 & 2.91 & .41 & 16.4 & 2.35 & 2.53 & .18 & 7.6 \\
Handwriting & 3.41 & 3.62 & .21 & 6.1 & 3.15 & 3.70 & .55 & 17.5 \\
\hline
\end{tabular}

Note: for statistically significant difference see Appendix 3 for detailed table of results.

Gains for EAL students, greater than Non EAL students, were evident in the authorial dimensions of writing, notably text structure and sentence structure. Vocabulary scores for this group of students also increased, though not at a rate significantly greater than their Non EAL peers. The texts of many EAL students demonstrated confident use of everyday vocabulary at both Times 1 and 2. EAL students' Handwriting also improved at a rate greater than their Non EAL peers. Handwriting of EAL students was slightly below the Non EAL students at Time 1 and slightly ahead at Time 2 . The rate of progress for punctuation was also greater for EAL students. However, this was not the case for spelling where the gains were greater for the Non EAL group.

\section{Associations between the dimensions the writing}

The data were also examined to explore patterns and relationships between the dimensions of writing and SES, using the ICSEA groupings. Table 5 shows the correlations between Time 1 and 2 and ICSEA on the dimensions assessed.

Evident in these analyses are the dimensions of writing that were associated with each other in the development of young writers. The highest correlations evident were between text structure and sentence structure $(r=.59)$ and text structure and vocabulary $(r=.60)$ at Time 1 . This pattern of association between these three authorial dimensions of writing showed a clear relationship between students' ability to control the organization of ideas, the grammatical patterns of sentences (syntax) and vocabulary choices. A similar pattern was evident at Time 2, where the highest correlations involved text structure and vocabulary $(r=.51)$. However, at Time 2 , text structure and spelling $(r=.49)$ were also associated, indicating a relationship between students' ability to compose and record messages accurately. The Time 1 and 2 correlations ranged from weak to moderate and show that students' attainment levels on the six dimensions measured were not static. The changes in the quality of the writing indicated there was malleability of the factors of interest. In addition, ICSEA groupings were significantly and weakly associated with the authorial dimensions and spelling but were not related to punctuation and handwriting.

Table 5: Correlations of the dimensions of writing at Time 1 and 2 and ICSEA groupings.

\begin{tabular}{lccccccc}
\hline & $\begin{array}{c}\text { Text } \\
\text { Structure }\end{array}$ & $\begin{array}{c}\text { Sentence } \\
\text { Structure }\end{array}$ & $\begin{array}{c}\text { Vocab- } \\
\text { ulary }\end{array}$ & Spelling & $\begin{array}{c}\text { Punct- } \\
\text { uation }\end{array}$ & $\begin{array}{c}\text { Hand- } \\
\text { writing }\end{array}$ & ICSEA $^{3}$ \\
\hline Text Structure $2^{1}$ & $.49^{* *^{2}}$ & $.59^{* *}$ & $.60^{* *}$ & $.39^{* *}$ & $.31^{* *}$ & $.28^{* *}$ & $.32^{* *}$ \\
Sentence Structure & $.41^{* *}$ & $.34^{* *}$ & $.64^{* *}$ & $.46^{* *}$ & $.34^{* *}$ & $.41^{* *}$ & $.21^{* *}$ \\
Vocabulary & $.51^{* *}$ & $.41^{* *}$ & $.46^{* *}$ & $.43^{* *}$ & $.31^{* *}$ & $.43^{* *}$ & $.26^{* *}$ \\
Spelling & $.49^{* *}$ & $.39^{* *}$ & $.41^{* *}$ & $.46^{* *}$ & $.44^{* *}$ & $.40^{* *}$ & $.19^{* *}$ \\
\hline
\end{tabular}




\begin{tabular}{|c|c|c|c|c|c|c|c|}
\hline $\begin{array}{l}\text { Punctuation } \\
\text { Handwriting }\end{array}$ & $\begin{array}{l}.34^{* * *} \\
.38^{* *}\end{array}$ & $\begin{array}{l}.34^{* *} \\
.37^{* *}\end{array}$ & $\begin{array}{l}.36^{* *} \\
.32^{* *}\end{array}$ & $\begin{array}{l}.32^{* *} \\
.43^{* *}\end{array}$ & $.34^{* * *}$ & $\begin{array}{l}.41^{* *} \\
.55^{* *}\end{array}$ & $\begin{array}{l}.12 \\
.11\end{array}$ \\
\hline
\end{tabular}

Note: ${ }^{1}$ Above the diagonal is Time 1 and below the diagonal is Time $2 .{ }^{2}$ Coefficients at the diagonals are correlations of Time 1 and $2 ;{ }^{3}$ ICSEA was constant at T1 and T2; ${ }^{* *}$ Indicates correlations are significant to or greater than .001 .

\section{Summary of findings}

The relationships between the three authorial dimensions of writing, as noted in the correlations and mean differences presented, demonstrate increased sophistication in the manner meaning is conveyed by young writers. The analysis indicated that the students made considered decisions about text structures, sentence structures and word choices (vocabulary). These three dimensions related to the overall organization of the text, leading to clarity and cohesion.

The growth in control over text structure and the type of texts produced were clearly evident in the data. At Time 1, a large number of students created texts which demonstrated the features of text structure skill levels 2, 3 and 4, with few achieving level 5. At Time 2, there was an increase in the number of texts demonstrating the text structure features of level 5, with less in levels 2, 3 and 4 . At Time 2, more students produced texts with evidence of the structure and features of particular text types, namely recount and narrative.

An emerging proficiency over sentence level grammar was also identified in the samples analysed. From the data it was difficult to tell whether minimal progress in this dimension was because of the level of challenge this area presented for students, the short time frame between samples one and two, or whether the teaching of grammar was more difficult than the other dimensions.

An increase in vocabulary choice was also evident in the text analysis from Time 1 to Time 2. In our study, it would appear that many children in Year 1 relied on everyday language and high frequency words, with the addition of more sophisticated and topic specific words in the second sample.

Most students who participated in our study were successfully able to: apply common letter-sound patterns to the writing of simple one-syllable words, use their visual memory to write high frequency wordsand apply morphemes appropriately. Some students were experimenting with more complex spelling patterns and demonstrating impressive, precocious lexical control. However the associations between vocabulary and spelling were not statistically strong, indicating possible tensions between accurate spelling and students' word choices when writing. The skills associated with capability in these areas require careful integrated teaching and possibly separate instruction in both.

Punctuation changed little over time, with most students only applying capital letters and full stops across both samples. However, it should be noted that where participants' writing was restricted to a simple or compound sentence, capital letters and full stops were often all that was needed. In other cases, the writing samples which included a number of sentences and variety of sentence structures, often demonstrated incomplete punctuation. 
The analysis of the handwriting in the samples proved to be quite difficult, given that we were unable to watch the process of letter and word construction. We are therefore only able to discuss handwriting in terms of how the writing appears in its final form. The majority students were able to write using unjoined lower case and upper case letters with growth evident across time in terms of spatial organization. There was improvement in the consistency of letter placement, appropriate spacing between words and regularity of letter size at Time 2. It was apparent, that for some students there was a relationship between the quality and quantity of the composition and the appearance of the handwriting. While this may be linked to a student's ability to construct ideas, it may also be linked to their ability to transcribe letters and words easily and fluently and therefore attend to the authorial requisites of the task.

The results for Time 1 and Time 2 were not static, with growth differentiated across the dimensions of writing and students' rates of learning highly individualized. There was not one single growth trajectory or pattern of learning evident in the data. Individual profiles indicated that while students made progress in one or more dimensions of writing other areas did not show improvement and in some cases regressed. Clay (1991:130) described this as "the pebble in the pond" effect, where a focus on a new feature of text may capture the child's attention and send ripples of disturbance through responses that had previously appeared well-established. This reflects the influence of student learning but also demonstrates that what teachers do can lead to changes in students' learning (Mackenzie 2011).

The result of the ICSEA analysis is typical of other measures of students' writing (ACARA 2013a) and also shows interesting patterns in the scores. While the levels of achievement were generally higher for children from higher ICSEA groups, the analysis of the authorial and secretarial dimensions indicated some variation across groups. The highest ICSEA group maintained strong control over text structure and sentence structure across both data collection points. The text analyses indicated these students were able to generate ideas and organise their texts using the features typical of the chosen genre. They also demonstrated use of a variety of sentence types to convey their meanings. However, scores for the secretarial aspects of writing were equal to or below that of the middle group. As the analysis was based on first or single draft texts, it may be that these students attend successively to these aspects of writing - ideas first and then a focus on the conventions specific to punctuation and handwriting. Alternatively these outcomes may reflect teaching emphases and priorities across the ICSEA cohort groups

Our analysis of the data reveals that the males in our study did not achieve the same standards as the females. However, many males achieved the female mean score and the gender difference between the boys and girls was statistically significant, but small. This suggests that the wider gaps in later grades, reported in other studies (e.g. Skelton and Francis 2011), may have their foundation in small differences observable in the early years. The data presented also cautions against generalising the 
literacy performance of boys, and suggests the possibilities of focused early interventions that interrupt patterns of performance, support accelerative learning and lead to improved outcomes (Clay 2001).

Although the EAL students in the study were a small group of 40, what is interesting about their growth, is that despite lower achievement scores at both Time 1 and Time 2, they made more growth than the Non EAL students in most dimensions over the same time period. Control over the quantity and quality of texts produced, and the complexity of sentence structures recorded by EAL students, may reflect increased levels of confidence and capacity in use of English or focused instruction aimed at improving EAL students' control over English.

\section{Discussion}

Learning to write using culturally determined conventions is a complex process that takes time and effort (Kellogg, 2008). Writers of all ages must learn to use the various codes and rules of a written form of language effectively as they work to create meaningful messages for particular purposes. Most often developing competency and rates of progress are measured with reference to curriculum frameworks and/or standards documents. This study provided a rare opportunity to examine a large sample of contemporary texts produced by young writers in order to determine the range of achievement, identify patterns of development and to project potential progress pathways. It is proposed that this process be considered complementary to the use of standardized and milestone based approaches. A close analysis of state and national curriculum documents and their relationship to the samples collected for this research is a possible area for future investigation.

Early control over the dimensions identified and discussed, is closely linked to young writers' understanding of the purpose of writing and their confidence and ability to engage in classroom writing tasks (Cutler and Graham 2008). In addition, early success with writing is important as it tends to lead to later success (Puranik and Lonigan 2014). In particular, control of the authorial dimensions of writing leads to text complexity and clarity of meaning. Our results support the need for explicit instruction in the creation of increasingly more complex grammatical structures at both the text and sentence levels as suggested by Gibbons (2002) and Christie (2005). While we found a relationship between the volume of writing and increased complexity, it is acknowledged that this relationship may spike early, and not extend beyond the early years of schooling. Further research is required to test this hypothesis. We would also argue that given the important link between vocabulary development and literacy (Beck, McKeown and Kucan 2013; Biemillar 2006, Dickinson and Porche 2011; Richgels 2004; Vellutino, Tunmer, Jaccard and Chen 2007), this is an area worthy of targeted teaching interventions.

The authorial dimensions of writing are supported by the efficient application of the secretarial dimensions (spelling, punctuation and handwriting). Attending to these surface features is cognitively demanding (Bromley 2007), but learning to apply them conventionally is necessary if a writer is to be able to express their ideas and meanings efficiently and unambiguously. While some of these 
secretarial skills may be learned coincidentally through reading, others require direct instruction (Cloonan, Scull and Turpin 1998). Again this points to the challenge complex sentence structures present for young writers and the need for focused instruction to develop understandings of punctuation that signal increasing levels of mastery and grammatical control. Moreover, this provides further evidence of the reciprocal relationship between the authorial and secretarial dimensions of writing.

\section{Limitations}

Despite the large sample set, there are a number of limitations that impact on the research discussed. Notwithstanding the number of participants, we had only two first draft texts per student available for analysis. A greater number of texts would enable us to better confirm students' abilities at the two data collection points and the growth patterns described. Furthermore, we acknowledge that the time between our two data gathering points was a period of four to five months in the second year of schooling. Data collection over a longer period of time, moving towards including a longitudinal study of writing achievement is needed to better demonstrate the changes over time in students' writing.

\section{Conclusion}

Our findings have been presented in terms of six writing dimensions: text structure, sentence structure, vocabulary use (the authorial dimensions of writing), spelling, punctuation and handwriting (the secretarial dimensions). The results highlight the characteristics of writing demonstrated by Year 1 students throughout the research period, identifying their level of attainment as measured by our analysis tool, and indicating associations and relationships across the six dimensions of writing. Despite the clearer picture of writing development and the range of attainment level this study provides, we are not arguing for a simplistic, linear pattern in learning to write. Instead, we acknowledge the intricate, individual progressions students make as they integrate the authorial and secretarial dimensions of composing and recording written texts. The findings of the study and the tool used to analyse the various dimensions of writing are offered to teachers and researchers, as a means to assist in assessing learning and planning for instruction, mapping student's individual pathways towards increased competence.

\section{References}

Abbott, R. D., Berninger, V. W., \& Fayol, M. (2010). Longitudinal relationships of levels of language in writing and between writing and reading in grades 1 to 7. Journal of Educational Psychology, 102(2), 281-298.

Anderson, M., \& Curtin, E. (2014). LLEAP 2013 Survey Report: Leading by evidence to maximise the impact of philanthropy in education. Melbourne, Vic: ACER.

Askew, B. J. (2009). Using an unusual lens. In B. Watson and B. J. Askew (Eds.), Marie Clay's search for the impossible in children's literacy, (pp. 101-127). North Shore NZ: Pearson Education. 
in reading, persuasive writing, language conventions and numeracy: National report for 2012. Sydney: ACARA.

http://www.nap.edu.au/verve/_resources/naplan_2012_national_report.pdf Accessed 28 May 2014.

Australian Curriculum, Assessment and Reporting Authority (ACARA). (2013a). NAPLAN achievement in reading, persuasive writing, language conventions and numeracy: National report for 2013. Sydney: ACARA. Accessed 21 February 2014.

Australian Curriculum, Assessment and Reporting Authority (ACARA). (2013b). The Australian curriculum. www.australiancurriculum.edu.au/ Accessed 13 August 2013.

Australian Curriculum, Assessment and Reporting Authority (ACARA; 2013c) Guide to understanding 2013 Index of Community Socio-educational Advantage (ICSEA) values. http://www.acara.edu.au/verve/_resources/Guide_to_understanding_2013_ICSEA_values.pdf Accessed April 102015

Australian Curriculum, Assessment and Reporting Authority (ACARA). (2014). NAPLAN achievement in reading, persuasive writing, language conventions and numeracy: National report for 2014. Sydney:

ACARA.http://www.nap.edu.au/verve/_resources/National_Assessment_Program_Literacy_a nd_Numeracy national_report_for_2014.pdf. Accessed 21 February 2014.

Beck, I. L., McKeown, M. G., and Kucan, L. (2013). Bringing words to life: Robust vocabulary instruction (2nd ed.). New York: The Guildford Press.

Below, J. L., Skinner, C. H., Fearrington, J. L. and Sorrell, C. A. (2010). Gender differences in early literacy: Analysis of kindergarten through fifth-grade dynamic indicators of basic early literacy skills probes. School Psychology Review, 39(2), 240-257.

Berninger, V. and Swanson, H. L. (1994). Modifying Hayes and Flowers' model of skilled writing to explain beginning and developing writing. In E. Butterfield (Ed.), Children's writing; Toward a process theory of development of skilled writing (pp. 57-81). Greenwich, CT: JAI Press.

Bernstein, B. (1970). Social class, language and socialization. In L. Burke, T. Crowley, \& A. Girvin (Eds.) (2000). The Routledge Language and Cultural Theory Reader. London: Routledge.

Biemiller, A. (2006). Vocabulary development and instruction: A prerequisite for school learning. In D. Dickinson and S. B. Neuman (Eds.), Handbook of early literacy research Vol. 2, (pp. 4151). New York: Guilford. 
Boscolo, P. (2008). Writing in primary school. In C. Bazerman (Ed.), Handbook of research on writing: History, society, school, individual, text (pp. 293-309). New York: Lawrence Erlbaum Associates.

Bromley, K. (2007). Best practices in teaching writing. In L. B. Gambrell, L. M. Morrow and M. Pressley (Eds.), Best practices in literacy instruction, (pp. 243-263). New York: The Guilford Press.

Christie, F. (2005). Language education in the primary years. Sydney: UNSW Press.

Clay, M. M. (1991). Becoming literate: The construction of inner control. Auckland: Heinemann.

Clay, M. M. (2001). Change over time: In children's literacy development. Portsmouth, NH: Heinemann.

Cloonan, A., Scull, J. \& Turpin, H. (1998). Teaching Writers in the Classroom. Melbourne: Longman.

Cohen, J. (1988). Statistical power analysis for the behavioral sciences, $2^{\text {nd }}$ edn. HillsdaleN J Lawrence Erlbaum Assoc.

Comber, B. (2004). Three little boys and their literacy trajectories. Australian Journal of Language and Literacy, 27(2), pp. 114-127

Connolly, P. (2004). Boys and schooling in the early years. London: Routledge Falmer.

Cummins, J. (2001). Negotiating identities: Education for empowerment in a diverse society, $2 \mathrm{nd}$ edn. Los Angeles, California Association for Bilingual Education.

Cutler, L. \& Graham, S. (2008). Primary grade writing instruction: A national survey. Journal of Educational Psychology, 100 (4), 907-919.

DiPrete, T. A. \& Jennings, J. L. (2012). Social and behavioral skills and the gender gap in early educational achievement, Social Science Research, 41(1), 1-15

Derewianka, B. (2011). A new grammar companion for teachers, 2nd edn. Marrickville, N.S.W.: Primary English Teaching Association.

Dickinson, D. K. \& Porche, M. V. (2011). Relation between language experiences in preschool classrooms and children's kindergarten and fourth-grade language and reading abilities. Child Development, 82(3), 870-886

Fang, Z., \& Wang, Z. (2011). Beyond rubrics: Using functional language analysis to evaluate student writing. Australian Journal of Language \& Literacy, 34(2), 147-165. 
Field, A. (2009). Discovering statistics using SPSS. New York: Sage publications.

Frow, J. (2005). Genre. New York NY: Routledge.

Ganske, K. (2000). Word journeys: Assessment-guided phonics, spelling, and vocabulary instruction. New York, NY: The Guilford Press.

Garcia, N., Abbott, R. \& Berninger, V. (2010). Predicting poor, average, and superior spellers in grades 1 to 6 from phonological, orthographic, and morphological, spelling, or reading composites. Written Language and Literacy, 13(1), 61-98.

Gentry, J. R. (1982). An analysis of developmental spelling in GNYS AT WORK. The Reading Teacher 36(2), 192-20.

Gibbons, P. (2002). Scaffolding language scaffolding learning. Portsmouth: Heinemann.

Gonski, D., Boston, K., Greiner, K., Lawrence, C., Scales, B., \& Tannock, P. (2011). Review of funding for schooling: Final report. Canberra, Department of Education, Employment and Workplace Relations. http://www.betterschools.gov.au/review Accessed 28 May 2015

Graham, S. (2009-2010). Want to improve children's writing? Don't neglect their handwriting. American Educator, Winter, 20-29.

Hodgetts, K. (2008). Underperformance or 'getting it right'? Constructions of gender and achievement in the Australian inquiry into boys' education. British Journal of Sociology of Education, 29(5), 465-477.

Jones, S. \& Myhill, D. (2004). 'Troublesome boys' and 'compliant girls': gender identify and perceptions of achievement. British Journal of Sociology of Education, 25(5), 547-561.

Kellogg, R. T. (2008). Training writing skills: A cognitive developmental perspective. Journal of Writing Research, 1(1), 1-26.

Lingard, B., Martino, W. \& Mills, M. (2009). Boys and schooling. London: Palgrave.

Lindsay, G. \& Muijs, D. (2006) Challenging underachievement in boys. Educational Research, 48 (3), 313-332.

Locke, T. (2010) Discovering a metalanguage for all seasons: Bringing literary language in from the cold, in T. Locke, (Ed.) Beyond the Grammar Wars. A Resource for Teachers and Students on Developing Language Knowledge in the English/Literacy Classroom, (pp. 170-184). New York: Routledge. 
Mackenzie, N.M. (2011). From drawing to writing: What happens when you shift teaching priorities in the first six months of school? Australian Journal of Language \& Literacy, 34(3), 322-340.

Mackenzie, N.M., Scull, J. \& Munsie, L. (2013). Analysing writing: the development of a tool for use in the early years of schooling, Issues in Educational Research, 23(3), 375-391.

Martin, J. R., Christie, F. \& Rothery, J. (1987). Social processes in education. In I. Reid (Ed.), The place of genre in learning, (pp. 58-82). Geelong: Centre for Studies in Literacy Education, Deakin University, (Typereader Publications 1)

Martino, W. (2003). Boys, masculinities and literacy: Addressing the issues. Australian Journal of Language and Literacy, 26(3),9-27.

McCarthey, S. J. \& Mkhize, D. (2013). Teachers' orientations towards writing. Journal of writing research, 5(1), 1-33.

McCutchen, D., Teske, P. \& Bankston, C. (2008). Writing and cognition: Implications of the cognitive architecture for learning to write and writing to learn. In C. Bazerman (Ed.), Handbook of research on writing, (pp. 451-470). New York: Lawrence Erlbaum Associates.Medwell, J. \& Wray, D. (2008). Handwriting - A forgotten language skill? Language and Education, 22 (1), $34-47$.

Mills, M., Martino, W. \& Lindgard, B. (2007). Getting boys' education 'right': the Australian government's parliamentary inquiry report as an exemplary instance of recuperative masculinity politics. British Journal of Sociology of Education, doi: $10.1080 / 01425690600995958$

Moats, L. C. (2005-2006). How spelling supports reading: And why it is more regular and predictable than you may think. American Educator, 29(4), 42-43.

Myhill, D. \& Fisher, R. (2010). Editorial: Writing development: cognitive, sociocultural, linguistic perspectives. Journal of Research in Reading, 33(1), 1-3.

Olson, D. R. (2009). The history of writing. In R. Beard, D. Myhill, J. Riley and M. Nystrand (Eds.), The Sage handbook of writing development, (pp. 6-16). London: SAGE.

Organisation for Economic Cooperation and Development (OECD) (2010). PISA 2009 at a glance. Geneva: OECD. http://www.oecd.org/pisa/pisaproducts/pisa2009/pisa2009keyfindings.htm Accessed May 282015

Perfetti, C., \& Hart, L. (2002). The lexical quality hypothesis. In L. Verhoeven, C. Elbro \& P. Reitsma (Eds.), Precursors of functional literacy (pp. 189-213). Philadelphia: John Benjamins Publishing Company. 
Peters, M.L. \& Smith, B. (1993). Spelling in context strategies for teachers and learners. Windsor, Berks: NFER-NELSON.

Puranik, C. S., \& Lonigan, C. J. (2014). Emergent writing in preschoolers: Preliminary evidence for a theoretical framework. Reading Research Quarterly, 49(4), 453-467. doi: 10.1002/rrq.79

Quinn, M. (2004) Talking with Jess: Looking at how metalanguage assisted explanation writing in the middle years. Australian Journal of Language and Literacy, 27(3), 245-261.

Raban, B. (1999). Language and literacy as epistemology. In J. S. Gaffney and B. J. Askew (Eds.), Stirring the waters: The influence of Marie Clay, (pp. 99-111). Portsmouth, NH: Heinemann.

Raban, B. (2014). TALK to think, learn and teach. Journal of Reading Recovery (Spring), 13 (2), 5-15.

Richgels, D. J. (2004). Paying attention to language. Reading Research Quarterly, 39, 470-477.

Ritchey, K. D. (2008). The building blocks of writing: Learning to write letters and spell words. Reading and Writing, 21(1-2), 27-47.

Schlagal, B. (2007). Best practices in spelling and handwriting. In S. Graham, C. A. MacArthur and J. Fitzgerald (Eds.), Best practices in writing instruction (pp. 179-201). New York: The Guilford Press.

Skelton, C. \& Francis, B. (2011). Successful boys and literacy: Are literate boys challenging or repackaging hegemonic masculinity? Curriculum Enquiry, , 41(4), 456-479, doi: 10.1111/j.1467-873X.2011.00559.x

Snow, C. E., Porche, M. V., Tabors, P.O. \& Harris, S.R. (2007). Is literacy enough? Pathways to academic success for adolescents. Baltimore: Paul H. Brookes.

Storch, S. A. \& Whitehurst, G. J. (2002). Oral language and code-related precursors to reading: Evidence from a longitunidal structural model. Developmental Psychology, 38(6), 934-947, doi: 10.1037//0012-1649.38.6.934

Teese, R., \& Lamb, S. (2009). Low achievement and social background: Patterns, processes and interventions. In Document de réflexion présenté au colloque de. http://lowsesschools.nsw.edu.au/Portals/0/upload/resfile/Low_achievement_and_social_backg ound_2008.pdf Accessed May 282015

Torrance, M. \& Galbraith, D. (2006). The processing demands of writing. In C. A. MacArthur, S. Graham and J. Fitzgerald (Eds.), Handbook of writing research (pp. 67-80). New York: The Guilford Press. 
Wasik, B. A. (2010). What teachers can do to promote preschoolers' vocabulary development:

Strategies from an effective language and literacy professional development coaching model. The Reading Teacher, 63(8), 621-633.

Whitehead, J. M. (2006). Starting school—why girls are already ahead of boys. Teacher Development, 10(2), 249-270, doi: 10.1080/13664530600773341

Whitmire, R. (2010). Why boys fail: Saving our sons from an educational system that's leaving them behind. New York: Amacom.

Wing Jan, L. (2009). Write ways: Modelling writing forms (3rd ed.). South Melbourne: Oxford.

Wulff, K., Kirk, C. \& Gillon, G (2008). The effects of integrated morphological awareness intervention on reading and spelling accuracy and spelling automaticity: A case study. New Zealand Journal of Speech-language Therapy, 63(3), 24-40.

Vellutino, F. R., Tunmer, W. E., Jaccard, J. J. and Chen, R. (2007). Components of reading ability: Multivariate evidence for a convergent skills model of reading development. Scientific Studies of Reading, 11 (1), 3-32.

Yates, L. (1997). Gender equity and the boys debate: What sort of challenge is it? British Journal of Sociology of Education, 18(3), 337-347.

Young, K. (2008). Don't just look, listen: Uncovering children's cognitive strategies during spellingrelated activities, Education 3-13, 36(2), 127-138, doi:10.1080/03004270701577164

Zbar, V., Kimber, R., \& Marshall, G. (2009). Schools that Achieve Extraordinary Success: How Some Disadvantaged Victorian Schools' punch Above Their Weight'. CSV/IARTV Occasional Paper 109, Victoria; Centre of Strategic Education. 
Appendix 1: Writing Analysis Tool

\begin{tabular}{|c|c|c|c|c|}
\hline Rating & Text Structure & $\begin{array}{l}\text { Sentence structure and } \\
\text { Grammatical features }\end{array}$ & Vocabulary & Spelling \\
\hline 1 & No clear message. & Random words. & $\begin{array}{l}\text { Records words of personal } \\
\text { significance, such as their } \\
\text { own name or those of } \\
\text { family members. }\end{array}$ & Random letters/letter like symbols \\
\hline 2 & $\begin{array}{l}\text { One or more ideas (not } \\
\text { related). }\end{array}$ & $\begin{array}{l}\text { Shows an awareness of correct } \\
\text { sentence parts, nouns/verb } \\
\text { agreement. May require } \\
\text { interpretation for meaning to } \\
\text { be construed. }\end{array}$ & $\begin{array}{l}\text { Uses familiar, common } \\
\text { words and two/three letter } \\
\text { high frequency words. }\end{array}$ & $\begin{array}{l}\text { Semi-phonetic, consonant framework, } \\
\text { alongside representation of dominant } \\
\text { vowel sounds. } \\
\text { Correct spelling of some two and thre } \\
\text { letter high frequency words (e.g. my, } \\
\text { to). }\end{array}$ \\
\hline 3 & Two or three related ideas. & $\begin{array}{l}\text { Simple sentence structure, } \\
\text { nouns, verbs, adverbs used. } \\
\text { Meaning clear. }\end{array}$ & $\begin{array}{l}\text { Everyday vocabulary, (Ref: } \\
\text { Oxford first } 307 \text { word list) }\end{array}$ & $\begin{array}{l}\text { Phonetic spelling -plausible attempts } \\
\text { with most sounds in words represent } \\
\text { Correct spelling of two and three lette } \\
\text { high frequency words (e.g. the, my, is, } \\
\text { to) }\end{array}$ \\
\hline 4 & $\begin{array}{l}\text { Four or more sequenced } \\
\text { ideas/events. Clearly } \\
\text { connected. }\end{array}$ & $\begin{array}{l}\text { Uses simple and compound } \\
\text { sentences with appropriate } \\
\text { conjunctions (e.g. and, but, } \\
\text { because, then) and adverbial } \\
\text { phrases to indicate when, } \\
\text { where, how, why, what. }\end{array}$ & $\begin{array}{l}\text { Uses a range of vocabulary, } \\
\text { including topic specific } \\
\text { words. }\end{array}$ & $\begin{array}{l}\text { Use of orthographic patterns or } \\
\text { common English letter sequences. If } \\
\text { incorrect they are plausible alternativ } \\
\text { (e.g. er for ir or ur; cort for caught). } \\
\text { Use of some digraphs (ck, ay). } \\
\text { Correct use of inflections (ed, ing). } \\
\text { Correct spelling of three/four letter hi } \\
\text { frequency words (e.g. was, like, here) }\end{array}$ \\
\hline 5 & $\begin{array}{l}\text { Evidence of structure and } \\
\text { features of genre (text } \\
\text { type). } \\
\text { Eg. Recount, narrative, } \\
\text { report structure and } \\
\text { features }\end{array}$ & $\begin{array}{l}\text { Uses a variety of sentence } \\
\text { structures: simple, compound } \\
\text { and complex sentences. } \\
\text { Consistent use of tense. } \\
\text { Pronoun reference correct to } \\
\text { track a character over } \\
\text { sentences. }\end{array}$ & $\begin{array}{l}\text { Includes descriptive or } \\
\text { emotive language. }\end{array}$ & $\begin{array}{l}\text { Use of some irregular spelling pattern } \\
\text { (e.g. light, cough) } \\
\text { Application of spelling rules (e.g. } \\
\text { hope/hoping, skip/skipping). } \\
\text { High frequency words spelt correctly } \\
\text { (e.g. there, their, where, were) }\end{array}$ \\
\hline 6 & $\begin{array}{l}\text { Complex text which shows: } \\
\text { - } \quad \text { Strong evidence of } \\
\text { features of genre (text } \\
\text { type) } \\
\text { - } \quad \text { Purpose and audience }\end{array}$ & $\begin{array}{l}\text { Demonstrates variety in } \\
\text { sentence structures, length, and } \\
\text { uses a variety of sentence } \\
\text { beginnings. Sentences flow with } \\
\text { logical sequence throughout the } \\
\text { piece. }\end{array}$ & $\begin{array}{l}\text { Correct use of technically } \\
\text { specific vocabulary and/or } \\
\text { figurative language. }\end{array}$ & $\begin{array}{l}\text { Correct spelling of most words } \\
\text { including multisyllabic and phonetica } \\
\text { irregular words. }\end{array}$ \\
\hline
\end{tabular}

Appendix 2

Means, Standard Deviations and Significance Statistics for Dimensions of Writing by Time and Gender at Time 1 and 2.

\begin{tabular}{|c|c|c|c|c|c|c|c|c|}
\hline \multirow[b]{2}{*}{ Time 1} & \multicolumn{2}{|c|}{ Females $(n=132)$} & \multicolumn{2}{|c|}{ Males $(n=118)$} & \multirow[b]{2}{*}{$F$} & \multirow[b]{2}{*}{ Sig. } & \multirow[b]{2}{*}{$\eta^{2}$} & \multirow[b]{2}{*}{$d$} \\
\hline & Mean & SD & Mean & SD & & & & \\
\hline \multicolumn{9}{|l|}{$\begin{array}{l}\text { Time } 1 \\
\text {. }\end{array}$} \\
\hline Text Structure & 4.32 & .97 & 3.89 & 1.04 & 11.33 & .001 & .04 & .43 \\
\hline Sentence Str & 3.73 & .75 & 3.47 & .71 & 8.38 & .004 & .03 & .36 \\
\hline Vocabulary & 3.67 & .81 & 3.50 & .74 & 2.88 & .091 & .01 & .22 \\
\hline Spelling & 3.34 & .82 & 3.25 & .79 & .87 & .353 & .01 & .12 \\
\hline Punctuation & 2.56 & .94 & 2.37 & .86 & 2.72 & .100 & .01 & .21 \\
\hline Handwriting & 3.49 & .90 & 3.23 & .97 & 4.98 & .027 & .02 & .28 \\
\hline \multicolumn{9}{|l|}{ Time 2} \\
\hline Text Structure & 4.55 & .73 & 4.34 & .97 & 3.91 & .049 & .02 & .25 \\
\hline Sentence Str & 3.78 & .65 & 3.62 & .70 & 3.59 & .059 & .01 & .24 \\
\hline Vocabulary & 4.14 & .66 & 3.92 & .63 & 7.21 & .008 & .03 & .35 \\
\hline Spelling & 3.62 & .85 & 3.36 & .80 & 6.39 & .012 & .03 & .32 \\
\hline
\end{tabular}




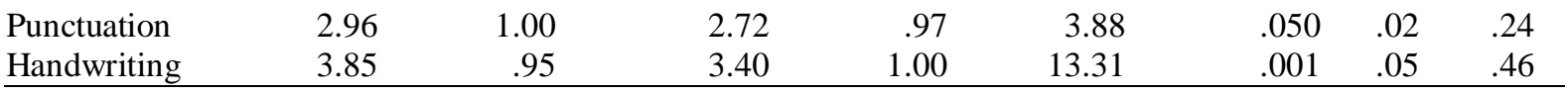

Appendix 3

Means, Standard Deviations and Significance Statistics for Dimensions of Language by EAL at Time 1 and 2.

\begin{tabular}{|c|c|c|c|c|c|c|c|c|}
\hline & \multicolumn{2}{|c|}{ NonEAL $(n=210)$} & \multicolumn{2}{|c|}{ EAL $(n=40)$} & \multirow[b]{2}{*}{$F$} & \multirow[b]{2}{*}{ Sig. } & \multirow[b]{2}{*}{$\eta^{2}$} & \multirow[b]{2}{*}{$d$} \\
\hline & Mean & SD & Mean & SD & & & & \\
\hline \multicolumn{9}{|l|}{ Time 1} \\
\hline Text Structure & 4.23 & .99 & 3.53 & .98 & 16.84 & .001 & .06 & .71 \\
\hline Sentence Str & 3.67 & .72 & 3.28 & .78 & 9.89 & .002 & .04 & .52 \\
\hline Vocabulary & 3.65 & .76 & 3.28 & .82 & 7.93 & .005 & .03 & .47 \\
\hline Spelling & 3.29 & .79 & 3.33 & .92 & .06 & .805 & .01 & .04 \\
\hline Punctuation & 2.50 & .93 & 2.35 & .74 & .87 & .351 & .01 & .03 \\
\hline Handwriting & 3.41 & .93 & 3.15 & .99 & 2.58 & .110 & .01 & .27 \\
\hline \multicolumn{9}{|l|}{ Time 2} \\
\hline Text Structure & 4.49 & .85 & 4.25 & .89 & 2.64 & .105 & .011 & .28 \\
\hline Sentence Str & 3.72 & .67 & 3.60 & .71 & 1.12 & .290 & .005 & .17 \\
\hline Vocabulary & 4.08 & .66 & 3.78 & .58 & 7.46 & .007 & .029 & .48 \\
\hline Spelling & 3.50 & .84 & 3.45 & .85 & .14 & .705 & .001 & .06 \\
\hline Punctuation & 2.91 & .99 & 2.53 & .81 & 5.33 & .022 & .021 & .42 \\
\hline Handwriting & 3.62 & .99 & 3.70 & .99 & .20 & .659 & .001 & .08 \\
\hline
\end{tabular}




\section{University Library}

\section{- M M N E R VA A gateway to Melbourne's research publications}

Minerva Access is the Institutional Repository of The University of Melbourne

Author/s:

Mackenzie, NM;Scull, J;Bowles, T

Title:

Writing over time: An analysis of texts created by Year One students

Date:

2015-11-01

Citation:

Mackenzie, N. M., Scull, J. \& Bowles, T. (2015). Writing over time: An analysis of texts created by Year One students. AUSTRALIAN EDUCATIONAL RESEARCHER, 42 (5), pp.567-593. https://doi.org/10.1007/s13384-015-0189-9.

Persistent Link:

http://hdl.handle.net/11343/282529 